\title{
Device Migration Problem
}

National Cancer Institute

\section{Source}

National Cancer Institute. Device Migration Problem. NCI Thesaurus. Code C133722.

Problem with all or part of an implanted or invasive device moving from its intended location within the body. 